Article

\title{
Inhalable Fucoidan Microparticles Combining Two Antitubercular Drugs with Potential Application in Pulmonary Tuberculosis Therapy
}

\author{
Ludmylla Cunha ${ }^{1,2}$, Susana Rodrigues $\left.{ }^{1,2} \mathbb{( D}^{(}\right)$, Ana M. Rosa da Costa ${ }^{3} \mathbb{( B}^{(}$, M Leonor Faleiro $^{1}$, \\ Francesca Buttini ${ }^{4}$ and Ana Grenha ${ }^{1,2, *(1)}$ \\ 1 Centre for Biomedical Research, University of Algarve, 8005-139 Faro, Portugal; \\ ludmyllacc@gmail.com (L.C.); susananasus@gmail.com (S.R.); mfaleiro@ualg.pt (M.L.F.) \\ 2 Centre for Marine Sciences, University of Algarve, 8005-139 Faro, Portugal \\ 3 Algarve Chemistry Research Centre and Department of Chemistry and Pharmacy, University of Algarve, \\ 8005-139 Faro, Portugal; amcosta@ualg.pt \\ 4 Food and Drug Department, University of Parma, 43124 Parma, Italy; francesca.buttini@unipr.it \\ * Correspondence: amgrenha@ualg.pt; Tel.: +351-289-244-441; Fax: +351-289-800-066
}

Received: 12 April 2018; Accepted: 31 May 2018; Published: 8 June 2018

\begin{abstract}
The pulmonary delivery of antitubercular drugs is a promising approach to treat lung tuberculosis. This strategy not only allows targeting the infected organ instantly, it can also reduce the systemic adverse effects of the antibiotics. In light of that, this work aimed at producing fucoidan-based inhalable microparticles that are able to associate a combination of two first-line antitubercular drugs in a single formulation. Fucoidan is a polysaccharide composed of chemical units that have been reported to be specifically recognised by alveolar macrophages (the hosts of Mycobacterium). Inhalable fucoidan microparticles were successfully produced, effectively associating isoniazid (97\%) and rifabutin (95\%) simultaneously. Furthermore, the produced microparticles presented adequate aerodynamic properties for pulmonary delivery with potential to reach the respiratory zone, with a mass median aerodynamic diameter (MMAD) between 3.6-3.9 $\mu \mathrm{m}$. The formulation evidenced no cytotoxic effects on lung epithelial cells (A549), although mild toxicity was observed on macrophage-differentiated THP-1 cells at the highest tested concentration $(1 \mathrm{mg} / \mathrm{mL})$. Fucoidan microparticles also exhibited a propensity to be captured by macrophages in a dose-dependent manner, as well as an ability to activate the target cells. Furthermore, drug-loaded microparticles effectively inhibited mycobacterial growth in vitro. Thus, the produced fucoidan microparticles are considered to hold potential as pulmonary delivery systems for the treatment of tuberculosis.
\end{abstract}

Keywords: alveolar macrophages; fucoidan; isoniazid; inhalable microparticles; rifabutin; spray-drying; tuberculosis therapy

\section{Introduction}

Tuberculosis (TB) is a leading infectious cause of death worldwide, even though a vaccine and several effective antibiotics are available for its prevention and treatment. According to the World Health Organisation (WHO), there were 10.4 million new TB cases globally and 1.3 million TB-related deaths in 2016 [1]. Global TB control is very difficult due to many factors, including late diagnosis and patient nonadherence to long-term treatments, which leads to a high incidence of extensive resistance to effective antitubercular drugs [2]. Besides drug resistance, the current therapy faces serious challenges, such as multi-drug interactions-especially with antiretroviral agents in cases of TB and HIV co-infection-long-term treatment, and antibiotic toxicity, which lead to adverse effects, 
resulting in patient non-compliance [3]. In this sense, accurate and early diagnosis are essential in TB therapy, in addition to patient adherence to the treatment and re-examination to verify the development of the active form of the disease. Moreover, in the treatment of TB, it must be considered the ability of Mycobacterium tuberculosis to survive intracellularly in the host alveolar macrophage for a long period. For that reason, therapy should ideally involve the intracellular delivery of antitubercular agents [4]. This could be achieved by the design of inhalable drug formulations with suitable aerodynamic properties to reach the alveoli, where macrophages infected with $M$. tuberculosis reside [5]. This strategy would potentially reduce the dosage and frequency of administration, and perhaps shorten treatment duration. As a result, systemic side effects could be avoided, improving patient adherence to the treatment [6].

In this context, fucoidan (FUC) could be used as the matrix material of the inhalable carriers to be designed. FUC is a promising biomaterial in this regard, because it presents sulphated fucose and other sugar residues [7], which can be recognised by the surface receptors of alveolar macrophages [8]. This can favour the internalisation of microparticles by alveolar macrophages, and subsequently, the delivery of drugs at the infection site. Furthermore, FUC can possibly intensify macrophage activation mediated by membrane receptors [9-11]. The working mechanism herein proposed for FUC microparticles is illustrated in Figure 1.

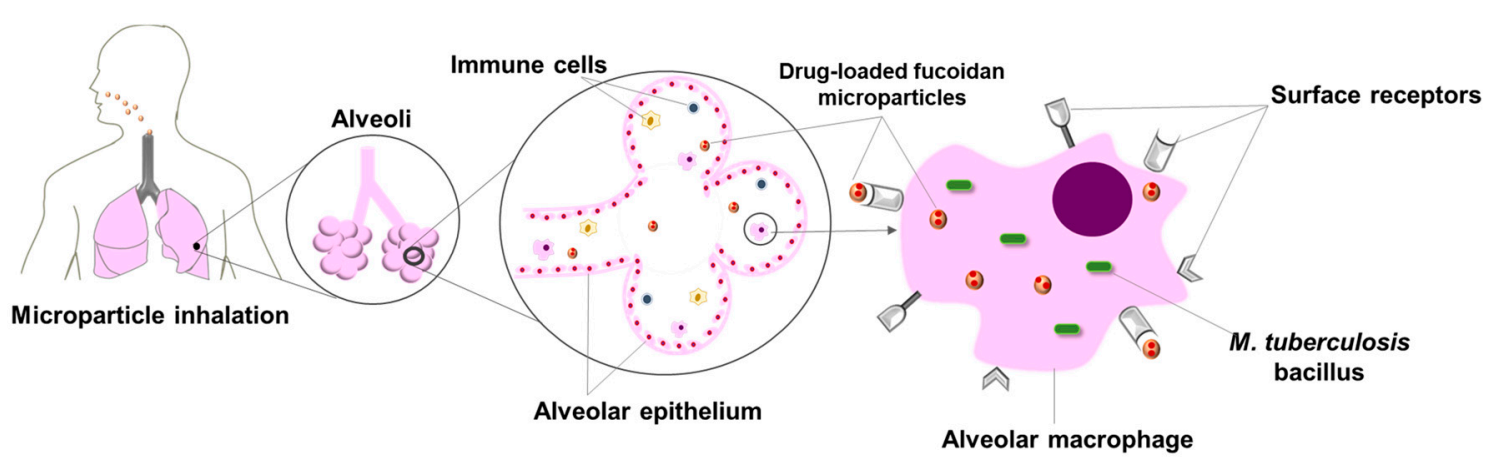

Figure 1. Illustration of microparticle uptake by alveolar macrophages, assuming targeted drug delivery mediated by fucoidan. Drug-loaded fucoidan microparticles reach the alveoli upon dry powder aerosolisation. Next, alveolar macrophages, infected with M. tuberculosis, engulf the microparticles. Fucoidan is expected to facilitate phagocytosis, because it possesses chemical moieties that are recognisable by the macrophage surface receptors.

The purpose of this work is to produce inhalable FUC-based microparticles combining both isoniazid (INH) and rifabutin (RFB) in a single formulation, with a potential affinity for alveolar macrophages mediated by FUC. The proposed combined therapy of INH and RFB complies with the specific WHO guidelines on TB therapy [12]. The microparticles were characterised and their respirability was evaluated to determine the ability to reach the deep lung. The uptake of FUC microparticles by macrophages was assessed by flow cytometry, and their capacity to activate macrophages was determined. The potential antimicrobial activity of the produced carriers was also evaluated, along with the determination of their cytocompatibility.

\section{Materials and Methods}

\subsection{Materials}

Fucoidan (FUC, Laminaria japonica) and rifabutin (RFB, $M_{\mathrm{W}} 847.00 \mathrm{~g} / \mathrm{mol}$ ) were purchased from Chemos $\mathrm{GmbH}$ (Regenstauf, Germany). Isoniazid (INH, $M_{\mathrm{w}} 137.14 \mathrm{~g} / \mathrm{mol}$ ), buffer solution $\mathrm{pH} 5$ (citric acid $\sim 0.096 \mathrm{M}$, sodium hydroxide $\sim 0.20 \mathrm{M}$ ), dimethylformamide (DMF), Dulbecco's modified Eagle's medium (DMEM), lipopolysaccharide (LPS), $N$-(3-dimethylaminopropyl)- $N^{\prime}$-ethylcarbodiimide hydrochloride (EDAC), non-essential amino acids solution and penicillin/streptomycin $(10,000 \mathrm{units} / \mathrm{mL}$, 
10,000 g/mL), sodium dodecyl sulphate (SDS), Triton-X 100, trypsin-EDTA solution (2.5 g/L trypsin, $0.5 \mathrm{~g} / \mathrm{L}$ EDTA), trypan blue solution ( $0.4 \%)$, and $\mathrm{HCl}$ were supplied by Sigma-Aldrich (Munich, Germany). Thiazolyl blue tetrazolium bromide (MTT), phosphate buffer saline (PBS) tablets $\mathrm{pH} 7.4$ and Tween $80^{\circledR}$ were supplied by Amresco (Solon, OH, USA). Dimethyl sulfoxide (DMSO) was provided by VWR (Fontenay-sous-Bois, France) and phorbol 12-myristate 13-acetate (PMA) was provided by Cayman Chemicals (Ann Arbor, MI, USA). A lactate dehydrogenase (LDH) kit was obtained from Takara Bio (Tokyo, Japan) and L-glutamine solution (200 mM), as well as fetal bovine serum (FBS) from Gibco (Life Technologies, Waltham, MA, USA). RPMI 1640 and Ham's F12 media were supplied by Lonza Group AG (Basel, Switzerland). Middlebrook 7H9 (M7H9; $4.7 \mathrm{~g} / \mathrm{L}$ ) and OADC (oleic acid, albumin, dextrose and catalase) were purchased from Remel (Lenexa, KS, USA). Ultrapure water (MilliQ, Millipore, UK) was used throughout the studies and other chemicals were reagent grade.

\subsection{Preparation of Microparticles}

Microparticles with and without drugs were obtained from 2\% (w/v) FUC solutions, which were prepared by dissolving the polymer in ultrapure water under stirring (MS-3000 Biosan, Riga, Latvia). The drugs INH and RFB were incorporated into the solution in two steps. INH was ground in a porcelain mortar, solubilised in water and then added dropwise to the prepared polymeric solution. RFB was ground in a glass mortar, dissolved in $4 \%(v / v)$ ethanol, and then incorporated drop by drop into the polymeric solution containing INH. The final solution $(50 \mathrm{~mL})$ was stirred for $1 \mathrm{~h}$ before spray-drying. Drugs were included in the formulation to obtain FUC/INH/RFB mass ratios of 10/1/0.5.

Microparticles were produced on a laboratory scale spray-dryer (Büchi B-290 Mini Spray Dryer, Büchi Labortechnik AG, Flawil, Switzerland), equipped with a high-performance cyclone. The equipment operated in open mode configuration, using compressed air. The spray flow rate was set at $473 \mathrm{~L} / \mathrm{h}$, and the operating parameters were set as indicated in Table 1.

Table 1. Operating parameters of the spray-drying process.

\begin{tabular}{cccc}
\hline Microparticles & Inlet T $\left({ }^{\circ} \mathbf{C}\right)$ & Aspirator $(\%)$ & Feed rate (mL/min) \\
\hline Unloaded FUC & $125 \pm 1$ & 80 & 2.0 \\
FUC/INH/RFB & $145 \pm 1$ & 85 & 1.0 \\
\hline
\end{tabular}

FUC: fucoidan; INH: isoniazid; RFB: rifabutin.

The production yield of the spray-drying process was calculated comparing the weight of collected microparticles and the total amount of solids initially added to produce microparticles. Dry powders were stored in desiccators until further use.

Fluorescent microparticles of FUC were also produced to be used in the assay of microparticle uptake by macrophages. To produce fluorescently labelled FUC, the covalent attachment of the dye to the polymer was carried out by reacting it with fluorescein sodium salt in the presence of $N$-(3-dimethylaminopropyl)- $N$ '-ethylcarbodiimide hydrochloride (EDAC) as activator of the fluorescein carboxyl group. In short, $1 \mathrm{~g}$ of FUC was dissolved at $2 \%(w / v)$ in water. Fluorescein sodium salt $(24.4 \mathrm{mg})$ dissolved in $4 \mathrm{~mL}$ of $96 \%(v / v)$ ethanol and EDAC ( $9.6 \mathrm{mg}$ dissolved in $16 \mathrm{~mL}$ of milli-Q water) were added to the former solution. The reaction mixture was kept under stirring in the dark overnight and afterwards dialysed (2000 Da $M_{\mathrm{w}}$ cut-off) against distilled water, which was also protected from the light. The dialysate was frozen and freeze-dried (FreeZone Benchtop Freeze Dry System, Labconco, Kansas City, MO, USA). Fluorescent (unloaded) FUC microparticles were prepared under the same conditions as displayed in Table 1. 


\subsection{Microparticle Characterisation}

\subsubsection{Morphology}

Microparticle morphology was visualised by field emission scanning electron microscopy (FESEM Ultra Plus, Zeiss, Jena, Germany). Briefly, the dry powder was placed onto metal plates and 5-nm thick iridium film was sputter-coated (model Q150T S/E/ES, Quorum Technologies, Lewes, UK) on the sample before visualisation.

\subsubsection{Feret's Diameter}

The microparticle size was estimated as the Feret's diameter and measured as the mean of 300 microparticles $(n=3)$. The measurements were performed by optical microscopy (Microscope TR 500, VWR international, Leuven, Belgium).

\subsubsection{Particle Size Distribution}

Drug-loaded FUC microparticles were characterised in terms of median volume diameter by laser light scattering. In short, an amount of dry powder $(15 \mathrm{mg})$ was dispersed in $15 \mathrm{~mL}$ of 2-propanol and sonicated for $5 \mathrm{~min}$. Measurements were performed with a SprayTec ${ }^{\circledR}$ (Malvern, UK) and data are expressed as $50 \%\left(D_{v} 50\right)$ of aerosol droplets. The analyses were performed three times with an obscuration threshold of $10 \%$ [13].

\subsubsection{Density}

A helium pycnometer (Micromeritics AccuPyc 1330, Aachen, Germany) was used to determine microparticle real density $\left(\mathrm{g} / \mathrm{cm}^{3} ; n=3\right)$. Tap density $\left(\mathrm{g} / \mathrm{cm}^{3}\right)$ was determined using a tap density tester ( $n=3 ; 30$ tapping/min, Densipro 250410, Deyman, Santiago de Compostela, Spain).

\subsection{Drug Association Efficiency and Loading}

In order to determine the drug content, the dry powder $(20 \mathrm{mg})$ was solubilised in $\mathrm{HCl} 0.1 \mathrm{M}$ $(10 \mathrm{~mL})$ under magnetic stirring for $20 \mathrm{~min}$. Then, the solution was filtered $(0.45 \mu \mathrm{m}, \mathrm{RC}$, Sartorius, Concord, CA, USA), and a sample was analysed by high-performance liquid chromatography (HPLC—Agilent 1100 series, Concord, Germany). A LiChrospher ${ }^{\circledR} 100$ RP-18 $(4.6 \mu \mathrm{m})$ column of $4 \mathrm{~mm}$ i.d. $\times 250 \mathrm{~mm}$ length with a security guard cartridge was used, and detection was performed by a diode array detector set at a wavelength of $275 \mathrm{~nm}$. For the analysis, the mobile phase consisted of phosphate buffer $20 \mathrm{mM} \mathrm{pH}=7$ (A) and acetonitrile (B), flowing at a rate of $1.0 \mathrm{~mL} / \mathrm{min}$. The elution was conducted with a gradient starting with $\mathrm{A} / \mathrm{B}=95 \% / 5 \%(0-5 \mathrm{~min})$, which further reached a $30 \% / 70 \% \mathrm{~A} / \mathrm{B}$ ratio (5-8 $\mathrm{min}$ ), which was kept for $19 \mathrm{~min}$. Under these conditions, retention times of INH and RFB were $5 \mathrm{~min}$ and $20 \mathrm{~min}$, respectively. Calibration curves $(10-400 \mathrm{mg} / \mathrm{mL})$ were plotted using INH and RFB standard solutions $(\mathrm{HCl} 0.1 \mathrm{M})$. Drug association efficiency and microparticle loading capacity were calculated $(n=3)$ by the following equations $[14,15]$ :

$$
\begin{gathered}
\mathrm{AE}(\%)=(\text { Real drug content/Theoretical drug content }) \times 100 \\
\mathrm{LC}(\%)=(\text { Real amount of drug } / \text { Weight of MP }) \times 100
\end{gathered}
$$

\subsection{In Vitro Drug Deposition}

The in vitro aerosolisation of the dry powder was evaluated using the Andersen cascade impactor (ACI, Copley Scientific Ltd., Nottingham, UK). The used methodology respected the USP38 guidelines for dry powder inhalers (Apparatus 1, United States Pharmacopoeia, Chapter 601). ACI separates particles according to their aerodynamic diameter, and it was assembled using the appropriate adaptor kit for the $60 \mathrm{~L} / \mathrm{min}$ air flow test. Cut-offs of the stages from -1 to 6 are the following: 8.60, 6.50, 4.40, $3.20,1.90,1.20,0.55$ and $0.26 \mu \mathrm{m}$. A glass fiber filter (Whatman, Milano, Italy) was placed right below 
stage six in order to collect particles with a diameter lower than that of the stage six cut-off. Collection plates were coated with $1 \%(v / v)$ Tween ${ }^{\circledR} 20$ in ethanol to prevent particle bounce.

A powder amount of $30 \mathrm{mg}$ was loaded into a size three HPMC capsule (Quali-V-I, Qualicaps, Madrid, Spain) and aerosolised using an RS01 device (IFR $=0.033 \mathrm{kPa}^{0.5} / \mathrm{LPM}$, Plastiape, Lecco, Italy). The content of three capsules was discharged for each experiment, and the experiments were performed in triplicate.

The flow rate that was used during each test was adjusted at $60 \mathrm{~L} / \mathrm{min}$ with a critical flow controller TPK (Copley Scientific, Nottingham, UK) in order to produce a pressure drop of $4 \mathrm{kPa}$ across the inhaler. The flow rate corresponding to these pressures was measured before each experiment using a DFM 2000 Flow Meter (Copley Scientific, Nottingham, UK). The test duration time was adjusted at $4 \mathrm{~s}$, so that a volume of $4 \mathrm{~L}$ of air was drawn through each inhaler during each test.

A mixture of water/acetonitrile $(50 / 50, v / v)$ was used to rinse off the powder from the apparatus. Samples were then sonicated for $5 \mathrm{~min}$, filtered $(0.45 \mu \mathrm{m}$, RC, Sartorius, Concord, CA, USA), and analysed by HPLC (Agilent 1200 series, Waldbronn, Germany), following the analytical protocol previously described.

The measurement of the INH and RFB that was deposited in the impactor allowed the calculation of deposition parameters. Mass median aerodynamic diameter (MMAD) was determined by plotting the cumulative percentage of mass less than the stated aerodynamic diameter for each stage on a probability scale versus the aerodynamic diameter of the stage on a logarithmic scale. The mass of drug particles with size $<5 \mu \mathrm{m}$ (calculated from log-probability plots) was defined as a fine particle dose (FPD). Yet, the amount of drug leaving the device and reaching the impactor was considered as the emitted dose (ED). Subsequently, the fine particle fraction (FPF) was calculated as the percentage ratio between FPD and ED. Finally, the metered dose (MD) was accounted as the mass of drug recovered and quantified by HPLC, and was calculated by summing the drug recovered from the inhaler (device and capsule) and the impactor (induction port, stages -1 to 6 and F).

\subsection{Drug Release Profiles}

The in vitro drug release studies were carried out in PBS (pH 7.4) and in buffer solution at $\mathrm{pH} 5$ (citric acid $\sim 0.096 \mathrm{M}$, sodium hydroxide $\sim 0.20 \mathrm{M}$, Sigma-Aldrich, Munich, Germany), both containing $1 \%(v / v)$ Tween ${ }^{\circledR} 80$. Assays were performed respecting sink conditions, as the maximum amount of drug was always below $30 \%$ of its maximum solubility [16]. The drug release rate was determined by incubating the dry powder $(20 \mathrm{mg})$ with a release medium $(10 \mathrm{~mL})$ in a test tube, which was kept at $37^{\circ} \mathrm{C}$ (Dry line; VWR, Tempe, AZ, USA) under mild shaking (100 rpm; Orbital Shaker OS 10, Biosan, Riga, Latvia). Then, at pre-established time intervals, aliquots $(1 \mathrm{~mL})$ were withdrawn, centrifuged $(16,000 \times g, 15 \mathrm{~min}$; Heraeus Fresco 17 Centrifuge, Thermo Scientific, Waltham, MA, USA), and filtered $(0.45 \mu \mathrm{m})$. In the end, the drug content in the samples was quantified by HPLC $(n=3)$ by interpolation from calibration curves obtained with standard solutions of drugs diluted in the release media.

\subsection{In Vitro Biocompatibility Studies}

\subsubsection{Cell Culture}

Human alveolar epithelium cells (A549) were purchased from the American Type Culture Collection (ATCC, Middlesex, UK). The cell line was cultured in DMEM supplemented with 10\% $(v / v)$ of FBS, 1\% (v/v) L-glutamine solution $200 \mathrm{mM}, 1 \%(v / v)$ non-essential amino acids, and $1 \%(v / v)$ penicillin/streptomycin. For the experiments, cells were used in passages 25-36.

THP-1 human monocytic cells were obtained from the Leibniz-Institute DSMZ (Braunschweig, Germany). The cell line was maintained in suspension at $0.2-0.8 \times 10^{6}$ cells $/ \mathrm{mL}$ in RPMI 1640 medium supplemented with 10\% $(v / v)$ FBS, $1 \%(v / v)$ L-glutamine, and 1\% $(v / v)$ penicillin/streptomycin. For the assays, THP- 1 cells $\left(0.35 \times 10^{6}\right.$ cells $\left./ \mathrm{mL}\right)$ were differentiated to acquire macrophage phenotype $(50 \mathrm{nM}$ PMA, 48 h) before performing the cytotoxicity tests. Cells were used between passages 10-17. 
In general, cell cultures were grown using $75 \mathrm{~cm}^{2}$ flasks in a humidified $5 \% \mathrm{CO}_{2} / 95 \%$ atmospheric air incubator at $37^{\circ} \mathrm{C}$ (HerAcell 150, Heraeus, Hanau, Germany).

\subsubsection{Determination of Metabolic Activity}

The effect of FUC microparticles on cell viability was evaluated on A549 and macrophagedifferentiated THP-1 cells by MTT assay. Briefly, A549 cells were seeded in 96-well plates (Orange Scientific, Braine-l'Alleud, Belgium) at a density of $1.0 \times 10^{4}$ cells/well in complete medium $(100 \mu \mathrm{L})$ and allowed to attach overnight at $37{ }^{\circ} \mathrm{C}$ in $5 \% \mathrm{CO}_{2}$ atmosphere. After that, cells were exposed to test solutions for 3 and $24 \mathrm{~h}$. After the exposure time, the medium was removed, and $30 \mu \mathrm{L}$ of MTT $\left(0.5 \mathrm{mg} / \mathrm{mL}\right.$ in PBS, pH 7.4) were added in each well, followed by $2 \mathrm{~h}$ of incubation at $37^{\circ} \mathrm{C}$. Next, purple crystals were dissolved with DMSO $(50 \mu \mathrm{L})$, and the absorbance was determined by spectrophotometry (Infinite M200, Tecan, Grödig, Austria) at $540 \mathrm{~nm}$, subtracting the background absorbance $(640 \mathrm{~nm})$.

Similarly, THP-1 cells were seeded in 96-well plates $\left(0.35 \times 10^{6}\right.$ cells/well) in $100 \mu \mathrm{L}$ of complete medium and differentiated as described before. After differentiation, the cell culture medium (CCM) was renewed for another $24 \mathrm{~h}$, before performing the experiments. As for A549 cells, exposure times of 3 and $24 \mathrm{~h}$ were applied. After exposure, MTT solution $(30 \mu \mathrm{L})$ was added in each well (no media removal was applied), and incubation was allowed for $2 \mathrm{~h}$, after which formazan crystals were solubilised with 10\% SDS in a 1:1 mixture of DMF. The absorbance was determined by spectrophotometry, as described above.

Overall, test solutions were previously prepared by dissolving the microparticles (unloaded and drug-loaded) in the proper CCM without FBS at three concentrations: $0.1,0.5$, and $1.0 \mathrm{mg} / \mathrm{mL}$. INH and RFB were also tested as free drugs at concentrations equivalent to their theoretical loadings in microparticles, i.e., $0.01,0.05$ and $0.1 \mathrm{mg} / \mathrm{mL}$ for INH and $0.005,0.025$ and $0.05 \mathrm{mg} / \mathrm{mL}$ for RFB.

CCM and $2 \%(w / v)$ SDS were used as positive and negative controls of cell viability, respectively. Cell viability of treated cells was expressed as a percentage of that observed for the positive control (CCM). The assay was performed at least three times, with six replicates at each concentration of test solutions.

\subsubsection{Evaluation of Cell Membrane Integrity}

The integrity of cell membrane was assessed by the quantification of LDH release upon exposure to test samples. Both A549 $\left(1.0 \times 10^{4}\right.$ cells/well $)$ and macrophage-differentiated THP-1 cells $\left(0.35 \times 10^{6}\right.$ cells/well $)$ were exposed to sample solutions at a concentration of $1.0 \mathrm{mg} / \mathrm{mL}$ (corresponding to the maximum concentration used in MTT assays). Solutions of free INH $(0.1 \mathrm{mg} / \mathrm{mL})$ and RFB $(0.05 \mathrm{mg} / \mathrm{mL})$ were also tested. After $24 \mathrm{~h}$ of exposure, aliquots $(100 \mu \mathrm{L})$ of cell supernatant samples were centrifuged $(16,000 \times g, 5 \mathrm{~min})$ and processed using a commercial LDH kit (Takara Bio, Tokyo, Japan). The concentration of LDH was measured by spectrophotometry (Infinite M200, Tecan, Grödig, Austria) at a wavelength of $490 \mathrm{~nm}$ with background correction at $690 \mathrm{~nm}$. Cells incubated with CCM only were considered the negative control; those treated with Triton-X100 (10\%) were used as the positive control, the latter being assumed as 100\% of LDH release. Thus, released LDH values were expressed as a percentage of the positive control. All of the measurements were performed in triplicate.

\subsection{Macrophage Activation by Microparticles}

In order to evaluate the capability of microparticles to activate macrophage-like cells, differentiated THP- 1 cells $\left(0.350 \times 10^{6}\right.$ cells /well $)$ were incubated with drug-loaded FUC microparticles. After $24 \mathrm{~h}$ of incubation, cell-free supernatants were collected and TNF- $\alpha$ and IL-8 quantified with Quantikine ${ }^{\circledR}$ HS ELISA kits (R\&D Systems, Minneapolis, MN, USA). The amount of each cytokine was expressed in $\mathrm{pg} / \mathrm{mL}$ based on reference standard curves. Cytokines released from cells treated with FUC solution 
and LPS, and untreated cells were used as controls. The absorbance of samples was determined at $450 \mathrm{~nm}$ in a microplate reader and corrected for background absorbance at $540 \mathrm{~nm}$.

\subsection{Preliminary Evaluation of Microparticle Uptake by Macrophages}

The uptake of FUC microparticles by macrophage-like cells was performed by flow cytometry (FacScalibur cell analyser, BD Biosciences, Erembodegem, Belgium) and involved the exposure of cells to fluorescently-labelled microparticles. The assay was performed on human macrophage-differentiated THP-1 cells and on rat alveolar macrophages (NR8383 cells). Macrophage-differentiated THP- $1\left(0.35 \times 10^{6}\right.$ cells $\left./ \mathrm{mL}\right)$ and NR8383 $\left(0.2 \times 10^{6}\right.$ cells $\left./ \mathrm{mL}\right)$ cells were seeded in $35 \mathrm{~mm}$-diameter dishes, containing $5 \mathrm{~mL}$ of the respective complete medium. Next, cells were maintained for $24 \mathrm{~h}$ at $37^{\circ} \mathrm{C}$ to ensure the adhesion of $50 \%-75 \%$ of the original population. Then, media were removed, and fluorescent microparticles (50 and $200 \mu \mathrm{g} / \mathrm{cm}^{2}$ ) were aerosolised onto the macrophage layer using a Dry Powder Insufflator ${ }^{\mathrm{TM}}$ (Model DP-4, Penn-Century ${ }^{\mathrm{TM}}$, Wyndmoor, PA, USA). Cells unexposed to microparticles were considered as negative control. The phagocytic process was allowed for $2 \mathrm{~h}$ (incubation at $37^{\circ} \mathrm{C}$ ) and was stopped by the addition of a cold solution of PBS.3\% FBS (5 mL, two applications). Then, cells were scraped, re-suspended in $3 \mathrm{~mL}$ of PBS.3\% and centrifuged (1500 rpm, 2 min, room temperature, centrifuge MPW-223e, MedInstruments, Warsaw, Poland). Cells were washed with PBS.3\% (5 mL) thrice and finally re-suspended in $1 \mathrm{~mL}$ of buffer for flow cytometry analysis (BD Biosciences FACSCalibur, Erembodegem, Belgium). For this purpose, side scatter light was used to distinguish cell viable population, whereas FSC-H and SSC-H channels were applied to measure the size and granularity of cells, respectively. A total of 10,000 events were counted within a gated region, and the data were presented as mean fluorescence (FL) intensity. The number of cells associated with fluorescence was considered the definition for uptake. The assay was replicated at least three times for each dose.

\subsection{Determination of Minimum Inhibitory Concentration (MIC)}

\subsubsection{Culture of Mycobacteria}

The in vitro efficacy of microparticles was evaluated against Mycobacterium bovis BCG (DSMZ 43990), provided, as a gift, by Centro de Estudos de Doenças Crónicas da Faculdade de Ciências Médicas da Universidade Nova de Lisboa (CEDOC/FCM-UNL). The stocks of mycobacteria were preserved and stored in $-80^{\circ} \mathrm{C}$ ultralow temperature freezers (U725 Innova New Brunswick Scientific, Edison, NJ, USA). Mycobacteria were cultivated in M7H9 broth, supplemented with $10 \%$ OADC and $0.05 \%$ of Tween ${ }^{\circledR} 80$. Mycobacteria was handled inside a laminar flow hood (Bio48 Faster, Cornaredo, Italy), respecting the guidance and safety requirements to prevent contamination. That includes autoclave sterilisation (Uniclave88, Sintra, Portugal) of infectious materials.

\subsubsection{MIC Measurements}

The lowest concentration of free antibiotics required to inhibit mycobacteria growth was determined by MTT assay [17]. Firstly, stock solutions $(1 \mathrm{mg} / \mathrm{mL})$ of INH and RFB were prepared by dissolving the drugs in the M7H9 supplemented medium. RFB was previously solubilised in ethanol, and then diluted with M7H9 broth. Stock solutions were filtered $(0.22-\mu \mathrm{m}$ sterile syringe filter) and mixed at concentrations proportional to the drug mass ratio contained in the microparticles $(\mathrm{FUC} / \mathrm{INH} / \mathrm{RFB}=10 / 1 / 0.5, w / w)$. The susceptibility of the $M$. bovis strain was then evaluated by incubating mycobacteria with a drug solution combining INH/RFB, followed by serial dilutions.

Similarly, the growth inhibition of mycobacteria promoted by FUC/INH/RFB microparticles was also assessed. A solution of dry powder was prepared at $1 \mathrm{mg} / \mathrm{mL}$ and then diluted, based on the calculations, to meet the desired drug concentrations. Generally, 96-well flat-bottom microplates (Orange Scientific, Braine-l'Alleud, Belgium) were filled with test samples, according to the scheme displayed in Figure S1 (Supplementary Materials). Three bacterial suspensions were prepared, and the 
assays were conducted after achieving an optical density value $\left(O D_{600 \mathrm{~nm}}\right)$ of approximately 0.2 , as measured by spectrophotometry (Infinite M200, Tecan, Austria). For the experiment, solutions (180 $\mu \mathrm{L})$ of free drugs or microparticles were added into the wells (column 4), making continuously serial two-fold dilutions with M7H9 supplemented broth (columns 5-11). Next, $20 \mu \mathrm{L}$ of bacterial suspension were added into the respective well, completing the final volume of $200 \mu \mathrm{L}$ per well. Wells filled only with M7H9 supplemented medium (column 2; $200 \mu \mathrm{L}$ ) were used as a negative control. Similarly, bacterial suspensions $(20 \mu \mathrm{L})$ were introduced in wells (column 3) containing M7H9 medium $(180 \mu \mathrm{L})$ in the absence of free drugs/microparticles, which were assumed as positive controls. The bacterial growth of each bacterial suspension-1, 2, and 3-was evaluated in the B-C, D-E, and F-G lines, respectively. Assays were performed in triplicate.

The outside lane of wells (a frame-like) were filled with sterile distilled water to avoid the evaporation of microplate content. The plates were covered with the lid, sealed with parafilm, and incubated at $37^{\circ} \mathrm{C}$ (Binder, Tempe, AZ, USA) for seven days. After that time, $30 \mu \mathrm{L}$ of MTT sterile solution was added to each well, followed by $1 \mathrm{~h}$ of incubation at $37^{\circ} \mathrm{C}$. Then, $50 \mu \mathrm{L}$ of DMSO was added into the wells, resulting in a colour change from yellow to dark gold proportional to the growth of mycobacteria. The absorbance was measured by spectrophotometry (Infinite M200, Tecan, Austria) at $540 \mathrm{~nm}$. The minimum inhibitory concentration was considered the one that inhibited mycobacteria growth by $95 \%$ to $100 \%$.

\subsection{Statistical Analysis}

Statistical significance was determined with the student $t$-test and one-way analysis of variance (ANOVA) with the pairwise multiple comparison procedures (Holm-Sidak method). A $p$-value of less than 0.05 was considered significant. Analysis was run using Sigmaplot software (version 12.5, Systat Software Inc., London, UK).

\section{Results and Discussion}

\subsection{Preparation and Characterisation of Fucoidan Microparticles}

Spray-dried FUC microparticles loaded with a combination of two first-line antitubercular drugs (INH and RFB) were produced with a yield around $81 \%$, indicating the effectiveness of the process. Drugs were efficiently associated to microparticles, with INH registering $97 \% \pm 4 \%$ and RFB 95\% $\pm 4 \%$ association efficiency. In this manner, loading capacities reached $8.5 \% \pm 0.4 \%$ (INH) and $4.1 \% \pm 0.2 \%$ (RFB), which were close to the theoretical values. This approach of associating antitubercular drugs in a single formulation meets the recommendations of the WHO regarding the need to establish a combined therapy for TB [12]. The selected theoretical drug loadings (8.7\% for INH and $4.4 \%$ for RFB) are similar to those reported in other works [18]. INH is present in a higher amount than RFB, because the latter is a more potent drug [19], and also has a more toxic profile, as demonstrated in Section 3.4. Moreover, fucoidan proportion was kept purposely high in order to favour macrophage internalisation [8].

The fact that both drugs were associated with similar efficiencies demonstrates that the process was independent of the aqueous solubility of the drugs $(125 \mathrm{mg} / \mathrm{mL}$ for $\mathrm{INH}$ and $0.19 \mathrm{mg} / \mathrm{mL}$ for RFB) $[20,21]$.

The morphological analysis performed with electronic microscopy revealed that the unloaded microparticles exhibited a slightly convoluted shape but smooth surface (Figure 2a). However, the incorporation of drugs in the microparticles produced important modifications on their morphology, which became more irregular and acquired corrugated surfaces (Figure 2b). In this case, the presence of RFB may have contributed to the morphological alterations perceived on the produced microparticles, as the observed surface wrinkles have been reported for other spray-dried microparticles loaded with RFB [22]. The wrinkled surface can also be thought of as a result of the drying process, in which the removal of ethanol from the microparticles' surface occurs faster than water evaporation. The higher 
volatility of ethanol induces the formation of a primary shell that collapses as the water content in the core evaporates [23].

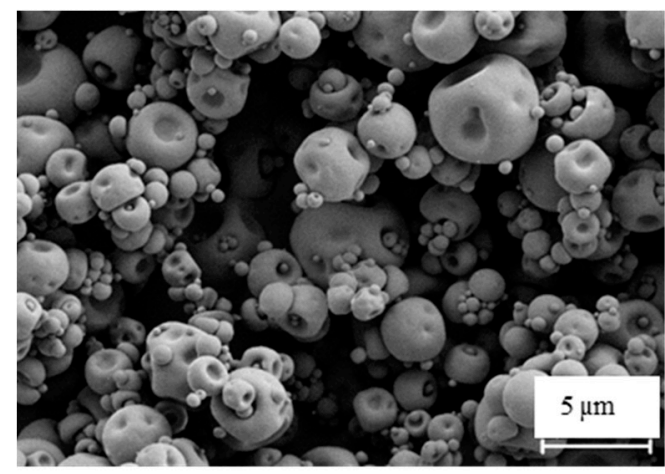

(a)

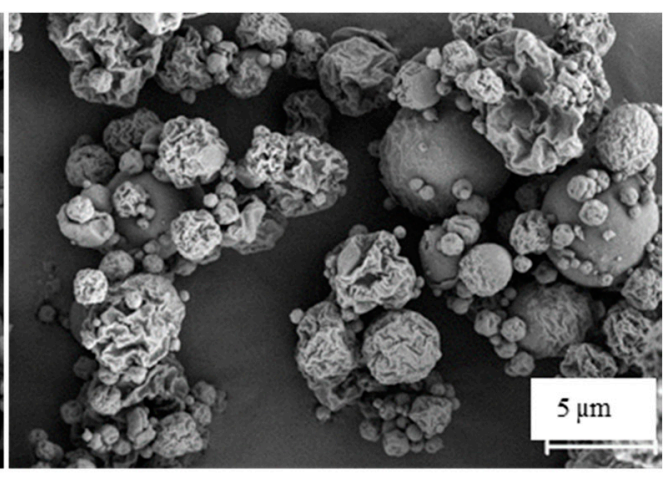

(b)

Figure 2. Scanning electron microphotographs of FUC-based microparticles: (a) unloaded microparticles and (b) FUC/INH/RFB microparticles. FUC: fucoidan, INH: isoniazid, RFB: rifabutin.

Drug-loaded microparticles were found to have a Feret's diameter of $1.4 \pm 0.8 \mu \mathrm{m}$; no significant differences were detected after drug incorporation $(1.6 \pm 0.8 \mu \mathrm{m}$ for unloaded FUC microparticles). Additionally, volume diameter measurement by laser light scattering indicated median diameters $\left(D_{\mathrm{v}} 50\right)$ of $2.77 \pm 0.03 \mu \mathrm{m}$ for drug-loaded microparticles. The latter indicates that the produced microparticles present a suitable size for pulmonary deposition [24]. The particle size distribution reflects the productive efficiency of spray-drying to provide microparticles with favourable aerodynamic properties for inhalation purposes [25]. To the best of our knowledge, this is the first report describing the use of spray-drying to produce respirable FUC-based microparticles loaded with two antitubercular drugs.

Density further influences the properties of inhalable dry powders [26]. Thus, real and tap densities of FUC microparticles were determined, showing values around $1.742 \pm 0.004 \mathrm{~g} / \mathrm{cm}^{3}$ and $0.346 \pm 0.019 \mathrm{~g} / \mathrm{cm}^{3}$, respectively. These results are similar to others reported for spray-dried polysaccharide microparticles $[27,28]$.

\subsection{Aerodynamic Characterisation of Fucoidan Microparticles}

The design of inhalable microparticles requires adequate flowability to promote lung deposition. In light of this, the in vitro aerosol performance was assessed in the ACI by using an RS01 dry powder inhaler. The obtained data are presented in Table 2.

Table 2. Aerodynamic parameters of fucoidan microparticles loaded with isoniazid (INH) and rifabutin (RFB) in the combined formulation. Loaded amount of powder in the capsule was $30 \mathrm{mg}$, corresponding to $2.6 \mathrm{mg}$ of INH and $1.4 \mathrm{mg}$ of RFB, according to the drug content of formulation $(n=3$, mean $\pm \mathrm{SD})$.

\begin{tabular}{cccccc}
\hline Drug & Metered Dose $(\mathbf{m g})$ & Emitted Dose $(\mathbf{m g})$ & MMAD $(\boldsymbol{\mu m})$ & FPD $<5 \boldsymbol{\mu m}(\mathbf{m g})$ & FPF $<5 \boldsymbol{\mu m}(\%)$ \\
\hline INH & $1.91 \pm 0.26$ & $1.64 \pm 0.23$ & $3.90 \pm 0.01$ & $0.82 \pm 0.02$ & $50.2 \pm 2.4$ \\
RFB & $1.29 \pm 0.03$ & $1.10 \pm 0.02$ & $3.64 \pm 0.32$ & $0.53 \pm 0.01$ & $45.4 \pm 1.4$ \\
\hline
\end{tabular}

FPD: fine particle dose; FPF: fine particle fraction; MMAD: mass median aerodynamic diameter.

The results demonstrated that more than $85 \%$ of the drugs were emitted from the device, indicating the suitability of FUC to be used as a matrix material in spray-dried inhalable microparticles. The adequate flowability is possibly a result of the wrinkled surfaces observed in the produced microparticles. Surface irregularities can reduce the cohesion forces between particles that lead to agglomeration, enhancing powder dispersibility, as well as improving the respirable fraction of the 
formulation [23,29]. This aspect is crucial when a lactose carrier is not included in the formulation, and spray-dried microparticles are aerosolised alone [16]. The FPF $(\leq 5 \mu \mathrm{m})$ was around $50 \%$, which represents the respirable fraction of microparticles with the potential ability to reach the respiratory zone. The results suggest as well that there was low cohesion among microparticles, which led to high deaggregation during aerosolisation and in agreement with the in vitro respirability usually exhibited by DPI formulation [24]. Additionally, the use of the RS01 device may have contributed to the maximisation of the performance, as it is described that the spinning capsule rotation provided by this inhaler is more efficient compared with the other capsule motion in the powder deaggregation [30,31].

Figure 3 illustrates the stage-by-stage deposition profiles of INH and RFB in the ACI after aerosolisation. The drug recovery varied between $82 \%-85 \%$, being in accordance with the values established by the European Pharmacopeia [32]. According to drug mass deposition on ACI stages, the determined MMAD values were $3.9 \mu \mathrm{m}$ (INH) and $3.6 \mu \mathrm{m}$ (RFB), suggesting a suitable size for lung deposition. In fact, particles with an aerodynamic diameter within the range of $1-5 \mu \mathrm{m}$ display a greater tendency for reaching the respiratory zone, and if with extrafine size $(<2 \mu \mathrm{m})$, have more peripheral deposition within the area [33]. Moreover, they are in the adequate size range $(1-6 \mu \mathrm{m})$ that allows phagocytosis by macrophage, the target cells [34].

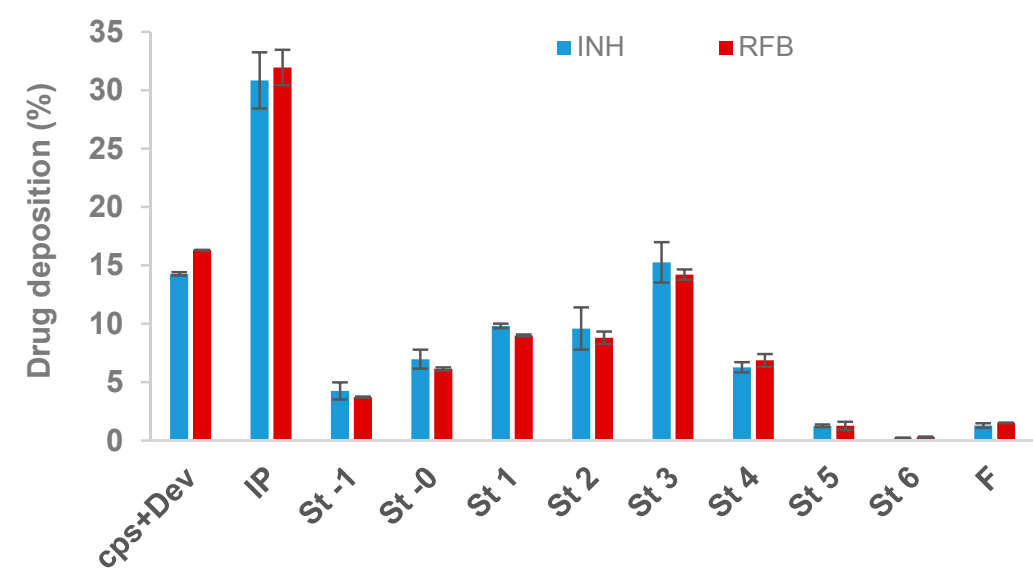

Figure 3. In vitro aerodynamic deposition of antitubercular drugs (INH and RFB) in the Andersen cascade impactor. Drugs were associated with spray-dried fucoidan microparticles. Values are mean \pm SD, $n=3$. Cps: capsule; Dev: inhaler device; IP: induction port; F: filter, INH: isoniazid; RFB: rifabutin St: stage.

The similarity between the profiles of both drugs demonstrates that INH and RFB were equally co-deposited on the several stages, thus supporting the decision of developing a delivery system with a combination of the two drugs. Furthermore, this indicates that the drugs have even distribution within the microparticles. In summary, the produced microparticles were shown to have adequate aerodynamic characteristics for the pulmonary delivery of antitubercular drugs with great propensity to reach the respiratory zone.

\subsection{In Vitro Drug Release Profiles}

The release of drugs was evaluated in PBS (pH 7.4) with the addition of $1 \%(v / v)$ Tween ${ }^{\circledR} 80$, resembling the lung lining fluid in terms of $\mathrm{pH}$ and the presence of surfactant $[35,36]$. The latter also enables the dissolution of RFB, which is sparingly soluble in aqueous media. Considering that alveolar macrophages are the target cells in this study, drug release studies were also conducted in more acidic medium ( $\mathrm{pH}$ ), simulating the phagolysosomal environment [37]. The obtained results are shown in Figure 4. 


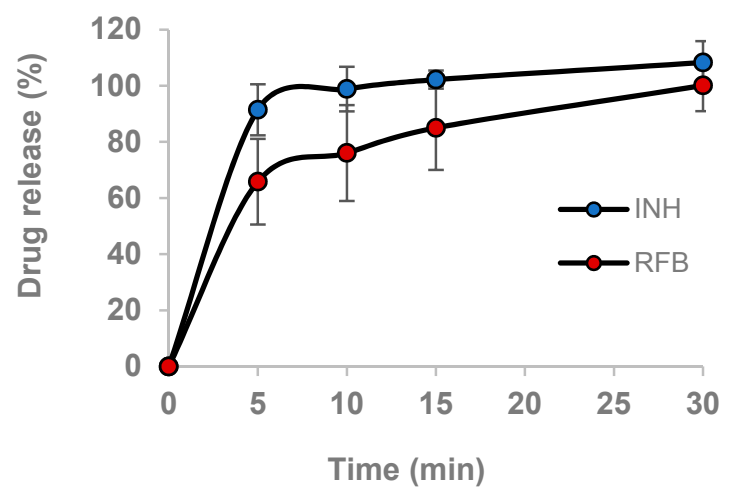

(a)

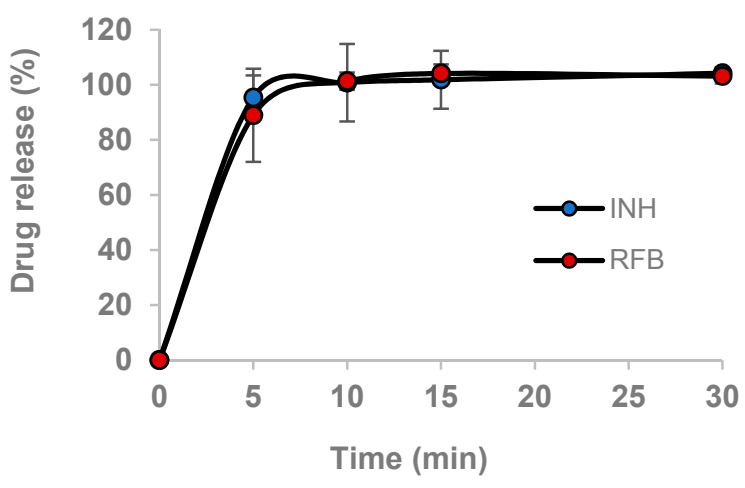

(b)

Figure 4. In vitro release profile of isoniazid (INH) and rifabutin (RFB) from FUC/INH/RFB (10/1/0.5, $w / w$ ) in (a) PBS pH 7.4-Tween $80^{\circledR}$ and (b) acidic medium pH 5.0-Tween $80^{\circledR}$. FUC: fucoidan; mean $\pm \mathrm{SD}, n=3$.

In general, the two drugs released rapidly from the microparticles, especially INH, which is completely available after $10 \mathrm{~min}$, disregard the $\mathrm{pH}$ of the release medium (Figure $4 \mathrm{a}, \mathrm{b}$ ). The rapid release of this drug was expected, owing to its high solubility in water. However, the RFB release profile was also similar to that of INH, despite its lower solubility. At $\mathrm{pH} 5$, RFB released exactly at the same rate as INH. In turn, at $\mathrm{pH} 7.4$, the release was a little bit slower, although not to a statistically significant level. In this medium, approximately $75 \%$ of the RFB was released within $10 \mathrm{~min}$, and $100 \%$ was released within $30 \mathrm{~min}$. The faster release in acidic medium is possibly a consequence of a certain protonation of the drug, which increases its solubility. However, no significant difference was perceived at any time point, indicating that the release of the two drugs was not significantly influenced by $\mathrm{pH}$. Other works also reported the rapid release of INH and RFB from polysaccharide microparticles [20,38].

The rapid release could be explained by two main factors: the surface irregularities, which increase the contact with the medium, and the high solubility of the polymeric matrix, i.e., FUC rapidly dissolves in the media, releasing the drugs. It should be stressed that these observations do not reflect in vivo occurrences, considering that a lower amount of liquid is present in the alveoli compared with that involved in the assays. It is well known that the alveolar epithelium is covered by a thin layer $(0.01-0.1 \mu \mathrm{m})$ of lung lining fluid, and thus, microparticles are expected to be only partially in contact with this fluid, and not immersed in it [39,40]. Consequently, in vivo drug release will probably occur more slowly, allowing microparticle internalisation by macrophage cells before particle dissolution and complete drug release.

\subsection{In Vitro Cytotoxicity}

The cytotoxicity of FUC/INH/RFB microparticles was evaluated by performing two complementary tests: metabolic assay (MTT) and the LDH release assay, which assesses cell membrane integrity. In both cases, alveolar epithelial cells (A549) and macrophage-differentiated THP-1 cells were used. Drug-loaded microparticles were tested along with an unloaded formulation and free drugs, which were considered as controls. Free drugs were tested at concentrations corresponding to the respective theoretical loading in the microparticles.

\subsubsection{Metabolic Activity by MTT Assay}

The MTT assay was performed upon 3 and $24 \mathrm{~h}$ of exposure, and revealed that the viability of the A549 cells exposed to the produced microparticles, in all of the tested conditions, remained above $70 \%$, the threshold below which it is considered the occurrence of cytotoxic effect according to ISO [41]. In fact, the exposure of A549 cells to FUC/INH/RFB microparticles induced mild effects on 
cell viability; meanwhile, no significant differences were observed in terms of time and microparticle concentrations (Figure 5a,b lighter colours). However, macrophage-differentiated THP-1 cells were slightly more sensitive to the contact with FUC/INH/RFB microparticles after long-time exposure. At $24 \mathrm{~h}$, cell viability decreased to $65 \%$ upon exposure to the highest dose of microparticles $(1.0 \mathrm{mg} / \mathrm{mL})$ (Figure 5b, darker colours). Comparatively, A549 cells showed 76\% viability in the same conditions $(p<0.05)$. Concerning macrophage-like THP-1 cells, no significant time-dependent or dose-dependent effects were observed.

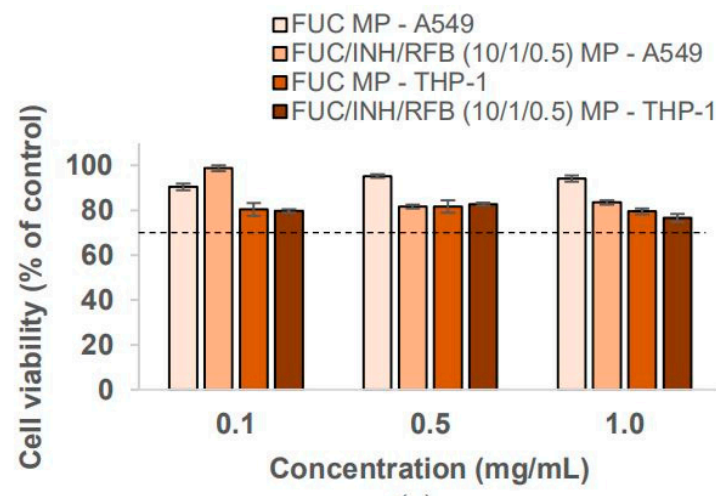

(a)

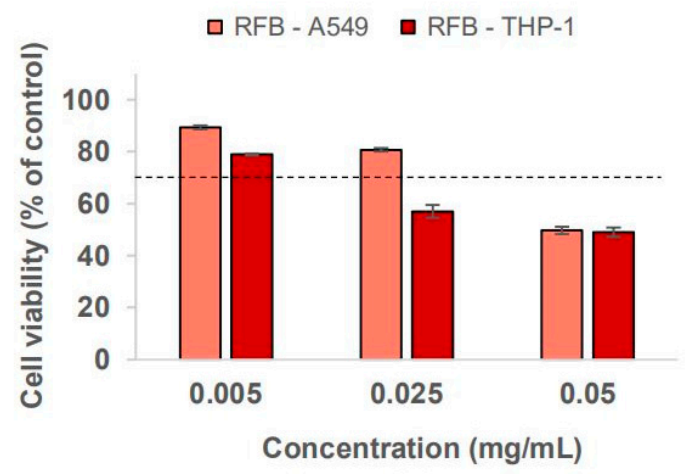

(c)

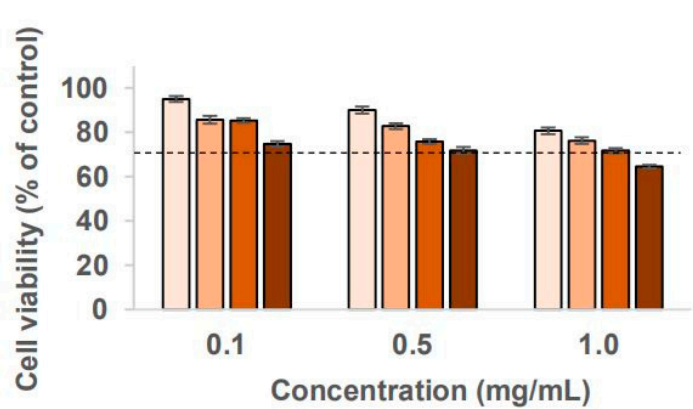

(b)

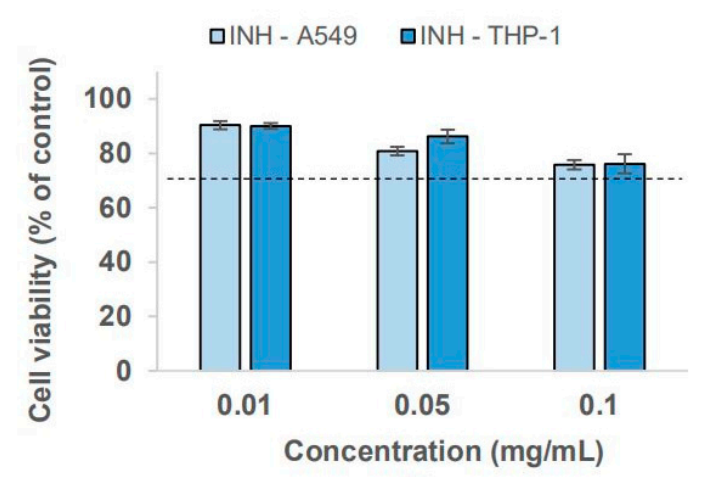

(d)

Figure 5. A549 and macrophage-differentiated THP-1 cell viability upon (a) $3 \mathrm{~h}$ and (b) $24 \mathrm{~h}$ of exposure to unloaded FUC and FUC/INH/RFB (10/1/0.5 w/w) microparticles; (c) 24 h exposure to RFB as a free drug; and (d) $24 \mathrm{~h}$ exposure to INH as a free drug. Cell viability was calculated as a percentage of positive control (untreated cells). Data represent mean \pm SEM $(n=3$, six replicates per experiment at each concentration). Dashed line indicates 70\% cell viability. FUC: fucoidan; INH: isoniazid; MP: microparticles; RFB: rifabutin.

The mild toxicity observed in THP-1 cells is clearly due to the RFB content, as was already described in a recent work of our group [42]. Figure $5 c, d$ depicts the effects of the free drugs after $24 \mathrm{~h}$. While INH induced cell viabilities between $75 \%-90 \%$ in both cell lines, thus not exhibiting a cytotoxic behaviour, RFB generated different responses. In fact, RFB decreased cell viability to around $50 \%$ in both cell types when tested at the highest concentration $(0.05 \mathrm{mg} / \mathrm{mL})$, while the viability of differentiated THP- 1 cells also decreased to $57 \%$ at the intermediate concentration $(0.025 \mathrm{mg} / \mathrm{mL}$, Figure $5 \mathrm{c}$ ). These observations demonstrated the drug toxicity, which has been reported in vivo [43,44], and indicated that the toxic effect is due to RFB. In order to further confirm this, drug-loaded microparticles were produced with lower amounts of RFB (FUC/INH/RFB $=10 / 1 / 0.2, w / w)$ to be purposely tested regarding cytotoxicity. It was verified that this decrease in RFB content resulted in the viability of differentiated THP- 1 cells over $70 \%$ in all of the tested concentrations (data not shown). Free drugs were also tested for $3 \mathrm{~h}$ (data not shown). INH induced the viability of $89 \%-99 \%$ in all of the cases. In turn, RFB decreased viability to $68 \%$ (A549 cells) and 56\% (differentiated THP-1 cells) at 
the highest tested concentration $(0.05 \mathrm{mg} / \mathrm{mL})$. It should be stressed that at the same time point $(3 \mathrm{~h})$, viability remained at $84 \%$ (A549) and 77\% (differentiated THP-1 cells) when cells were exposed to FUC/INH/RFB microparticles $(1.0 \mathrm{mg} / \mathrm{mL})$, as shown in Figure $5 \mathrm{a}$. In this way, it is suggested that the microencapsulation had a beneficial effect on RFB cytotoxicity $(p<0.05)$. Unloaded FUC microparticles were also tested as control in both cell lines (Figure $5 \mathrm{a}, \mathrm{b}$ ), resulting in a cell viability above $80 \%$ in all of the cases, thus evidencing the absence of detrimental effects of the polysaccharide under the tested conditions.

Overall, it can be considered that both A549 and macrophage-differentiated cells tolerated the exposure to fucoidan-based microparticles well. A single exception was registered in macrophage-like THP- 1 cells when exposed to $1.0 \mathrm{mg} / \mathrm{mL}$ microparticles for $24 \mathrm{~h}$, with the toxicity being attributed to the RFB content. However, it should be highlighted that this dose is much higher than the one that was expected to occur in vivo, as after the delivery, the dry powder will be distributed through a large surface. Therefore, the effects will probably be more similar to those of the lower doses ( 0.1 and $0.5 \mathrm{mg} / \mathrm{mL}$ ), which were concentrations where no cytotoxicity was perceived.

\subsubsection{Cell Membrane Integrity}

As a complement to the MTT assay, the amount of the cytoplasmic enzyme LDH released after cell exposure $(24 \mathrm{~h})$ to microparticles $(1.0 \mathrm{mg} / \mathrm{mL})$ and free drugs was determined (Figure 6). The results essentially confirm those of MTT, with free RFB having a more intense effect on the release of LDH. The incubation with CCM induced 21\% of LDH release in A549 cells (Figure 6a) and 34\% in macrophage-differentiated THP-1 cells (Figure 6b). The exposure to free RFB significantly increased these values to $42 \%$ and $57 \%$, respectively $(p<0.05)$. Despite RFB cytotoxicity, FUC/INH/RFB microparticles generated similar LDH release compared with CCM in both cell lines, which reinforces the beneficial effect of microencapsulation regarding RFB cytotoxicity.

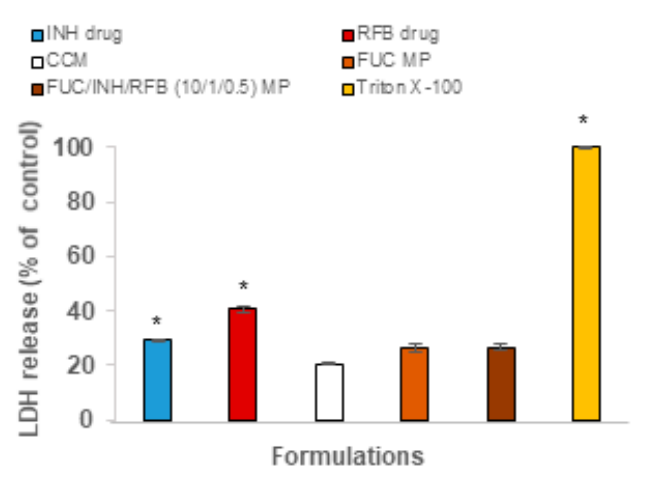

(a)

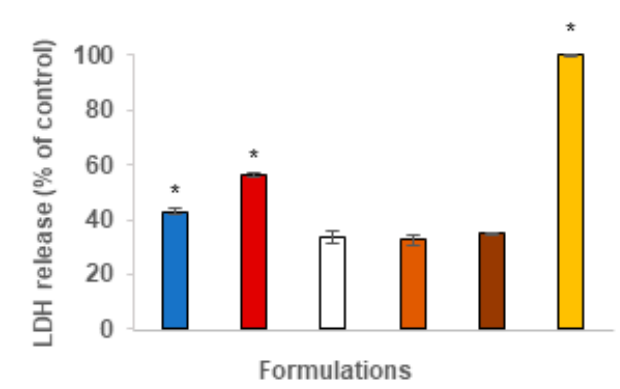

(b)

Figure 6. Release of lactate dehydrogenase (LDH) from (a) A549 cells and (b) macrophage-differentiated THP-1 cells exposed to fucoidan-based microparticles $(1.0 \mathrm{mg} / \mathrm{mL})$, free rifabutin (RFB, $0.05 \mathrm{mg} / \mathrm{mL}$ ), and free isoniazid (INH, $0.1 \mathrm{mg} / \mathrm{mL}$ ). Cell culture medium (CCM) and Triton X-100 were used as negative and positive controls, respectively. The released LDH calculated was based on $100 \%$ assumed for positive control. Data represent mean $\pm \operatorname{SEM}(n=3$, six replicates per experiment at each concentration). ${ }^{*} p<0.05$ compared to CCM.

Curiously, free INH also induced the release of a significantly higher amount of LDH compared with the control CCM ( $29 \%$ for A549 cells and $43 \%$ for macrophage-differentiated THP- 1 cells, $p<0.05$ ). However, microencapsulation reverted the toxicological effect $(p<0.05)$. Unloaded FUC microparticles also evidenced an absence of effect on LDH release.

The overall evaluation of in vitro cytotoxicity indicates a very acceptable toxicological profile of FUC-based microparticles. Nevertheless, it is considered beneficial to widen the toxicological studies of these microparticles to certify their use for the proposed application. 


\subsection{Macrophage Activation}

The ability of FUC/INH/RFB microparticles to induce macrophage activation was assessed by determining the amount of TNF- $\alpha$ and IL- 8 secreted by macrophage-like THP- 1 cells upon contact with the formulation. The referred cytokines are two pro-inflammatory molecules released by human alveolar macrophages upon infection with $M$. tuberculosis [45,46]. The synthesis of pro-inflammatory cytokines such as TNF- $\alpha$ and IL- 8 by macrophages contributes to the effective control of the proliferation and dissemination of pathogens [47]. The amount of secreted cytokines was compared with the levels produced upon stimulation with LPS (positive control) and untreated cells (negative control).

Figure 7 depicts the obtained results. The contact with drug-loaded FUC microparticles induced TNF- $\alpha$ concentrations of $1.5 \times 10^{3} \mathrm{pg} / \mathrm{mL}$ (Figure 7a), which did not differ statistically from the value registered upon LPS stimulation, although the nominal value was higher in that case $\left(2.5 \times 10^{3} \mathrm{pg} / \mathrm{mL}\right)$. This observation is in agreement with a recent report showing that that FUC induces TNF- $\alpha$ secretion from macrophage-differentiated THP-1 cells [48]. FUC was also tested as a solution, which gives an indication of the effect of the polymer itself. It was shown to induce the production of TNF- $\alpha\left(1.9 \times 10^{3} \mathrm{pg} / \mathrm{mL}\right)$, which is not statistically different from the effect of microparticles. Importantly, when comparing with CCM, the induced TNF- $\alpha$ production was higher for both FUC microparticles and FUC solution $(p<0.05)$.
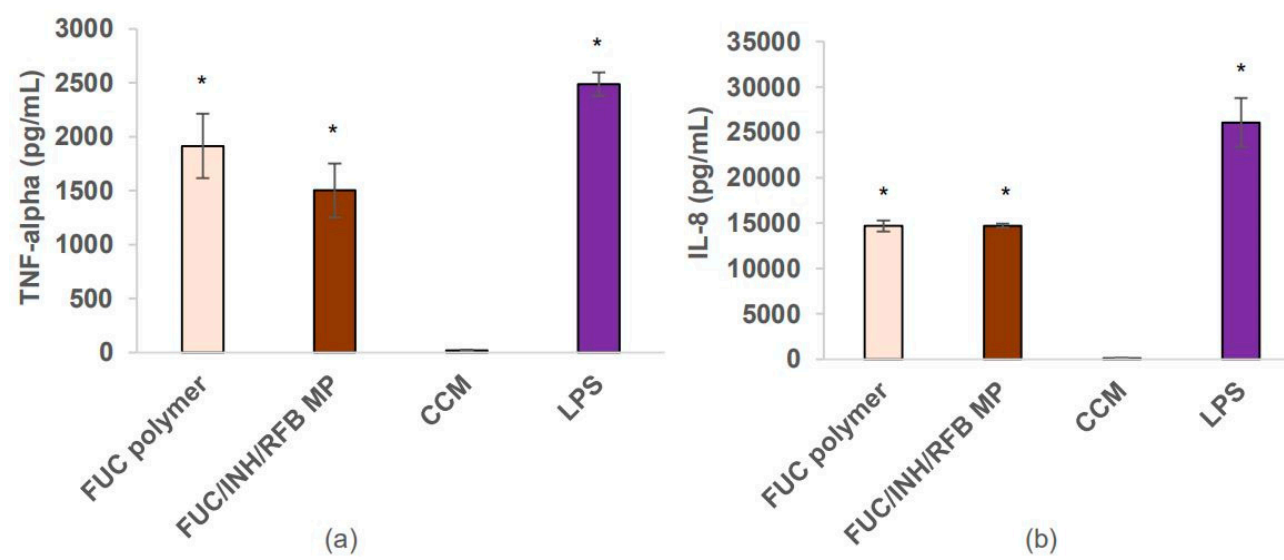

Figure 7. Assessment of (a) TNF- $\alpha$ and (b) IL-8 secretion induced by FUC/INH/RFB microparticles and FUC as the raw material. Lipopolysaccharide (LPS) and cell culture medium (CCM) were used as controls. FUC: fucoidan; INH: isoniazid; RFB: rifabutin. Data represent mean $\pm \operatorname{SEM}(n=3) .{ }^{*} p<0.05$ compared to CCM.

Similar effects were observed regarding the production of IL-8 (Figure 7b). Although in this case, LPS generated a significantly higher amount of cytokine $\left(26 \times 10^{3} \mathrm{pg} / \mathrm{mL}, p<0.05\right)$, drug-loaded FUC microparticles also revealed an ability to induce its secretion, which reached $14.7 \times 10^{3} \mathrm{pg} / \mathrm{mL}$, more than half of the amount corresponding to LPS. Moreover, IL-8 secretion stimulated by the produced microparticles and raw material were much higher than that of the control CCM $(p<0.05)$.

Overall, no significant differences were observed in the production of each interleukin upon stimulation by FUC/INH/RFB microparticles and the raw material FUC. In this way, the results suggest that FUC is the agent responsible for the observed activation of macrophage-like cells. Actually, the immune modulatory activity of FUC has been already reported, and is mediated through the regulation of immune cells, including macrophages [49,50]. Although FUC has been shown to induce the production of TNF- $\alpha$ [11,48] and IL-8 [51] from macrophages and other immune cells [9], the polymer seems to be endowed with anti-inflammatory activity as well. In truth, the mechanism of action of FUC as a bioactive agent is yet to be unveiled [52,53], and this is an area worth researching. 


\subsection{Preliminary Evaluation of Microparticle Uptake by Macrophage-Like Cells}

Taking into consideration the intended application of the developed microparticles, the ability of macrophage cells to internalise the carriers was assessed by flow cytometry. Macrophage-differentiated THP-1 cells and rat alveolar macrophages NR8383 were exposed to two different doses of microparticles. As depicted in Figure 8, the percentage of THP-1 cells taking up FUC microparticles were around $23 \%\left(50 \mu \mathrm{g} / \mathrm{cm}^{2}\right)$ and $87 \%\left(200 \mu \mathrm{g} / \mathrm{cm}^{2}\right)$, demonstrating a dose-dependent uptake $(p<0.05)$. Similarly, the cellular uptake of carriers by rat macrophages varied between $68 \%-86 \%$ as the concentration raised from 50 to $200 \mu \mathrm{g} / \mathrm{cm}^{2}$, also revealing a dose-dependent effect $(p<0.05)$. Significant differences $(p<0.05)$ were observed between the uptake by both cell lines, particularly at the lowest tested dose $\left(50 \mu \mathrm{g} / \mathrm{cm}^{2}\right)$. In this case, $23 \%$ and $68 \%$ of FUC microparticles were taken up by THP- 1 cells and NR8383 cells, respectively. Therefore, the obtained results are a preliminary demonstration of the macrophage's ability to uptake FUC microparticles at a considerable level, depending on the dose. Considering that FUC exhibits in its structure of chemical motifs (sulphate groups and sugar units) that can be recognised by macrophage surface receptors [8], a more accurate determination of preferential macrophage phagocytosis would be provided by comparing the uptake of FUC microparticles with a material devoid of recognisable moieties. Additionally, complementing cytometry data with confocal microscopy images would be beneficial in corroborating the data obtained so far.

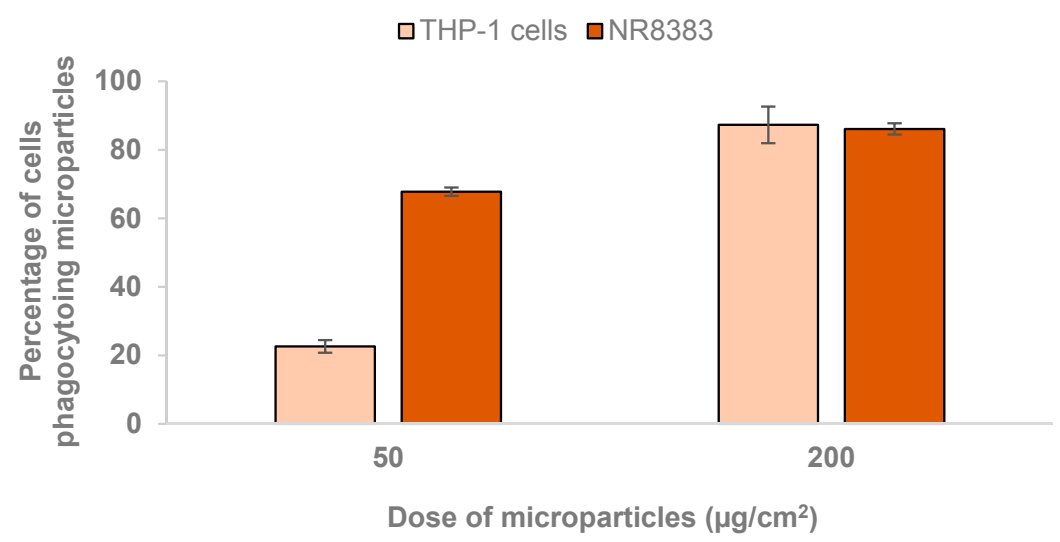

Figure 8. Uptake of fluorescently-labelled fucoidan (FUC) microparticles by macrophage-differentiated THP- 1 cells and NR8383 cells exposure to $50 \mu \mathrm{g} / \mathrm{cm}^{2}$ and $200 \mu \mathrm{g} / \mathrm{cm}^{2}$, for a period of $2 \mathrm{~h}$. Results are expressed as mean $\pm \operatorname{SEM}(n \geq 3)$.

\subsection{Determination of Minimum Inhibitory Concentration}

In order to measure the minimum inhibitory concentration of the produced systems, $M$. bovis cells were treated with free drugs and FUC/INH/RFB microparticles. The viability of mycobacteria upon exposure to tested samples was calculated as a percentage of bacterial culture (control), which was considered as $100 \%$ of bacterial growth.

The MIC value determined for INH as free drug was $0.125 \mu \mathrm{g} / \mathrm{mL}$, which is in the value range reported in the literature [54,55]. Comparatively, free RFB at a concentration of $0.004 \mu \mathrm{g} / \mathrm{mL}$ was sufficient to inhibit the growth of $M$. bovis, suggesting that RFB is a stronger antimycobacterial agent than INH, probably due to the higher lipophilicity that facilitates its internalisation through the cell membrane [56,57]. The literature reports variable MIC values of RFB, depending on the strain of $M$. bovis and on the method of susceptibility testing [58,59]. By combining both INH and RFB as free drugs in a single solution, the determined MIC values were $0.008 \mu \mathrm{g} / \mathrm{mL}$ (INH) and $0.004 \mu \mathrm{g} / \mathrm{mL}$ (RFB). It is worth noting that the MIC of INH reduced from 0.125 to $0.008 \mu \mathrm{g} / \mathrm{mL}$ when combined with RFB. Differently, either alone or in combination, RFB displayed the same MIC value $(0.004 \mu \mathrm{g} / \mathrm{mL})$. This indicates that the in vitro susceptibility of mycobacteria to INH is potentiated when the two antitubercular drugs were applied together. 
By exposing $M$. bovis to $0.08 \mu \mathrm{g} / \mathrm{mL}$ of $\mathrm{FUC} / \mathrm{INH} / \mathrm{RFB}$ microparticles, the viability of mycobacteria decreased to the minimum level, therefore being the referred concentration of the MIC value of the produced systems. It is important to highlight that, at this microparticle concentration, the drug content, considering their respective association efficiency, is approximately $0.008 \mu \mathrm{g} / \mathrm{mL}$ (INH) and $0.004 \mu \mathrm{g} / \mathrm{mL}$ (RFB). These concentrations correspond to the MIC values determined for the two drugs when tested in combination (as free drugs). Therefore, the inhibition effect on the growth of $M$. bovis was very similar when comparing drug-loaded FUC microparticles and the mixed solution of $\mathrm{INH} / \mathrm{RFB}$ as free drugs. This observation indicates that the microencapsulation process had no effect on the antibacterial activity of the drugs. In summary, an in vitro susceptibility of $M$. bovis has been observed towards drug-loaded FUC microparticles with considerable growth inhibition, as expected.

\section{Conclusions}

Inhalable dry powders based on FUC were produced to associate two first-line antitubercular drugs (INH and RFB) in a single formulation. Spray-dried microparticles were produced with high drug association efficiencies ( $>95 \%$ ) and displayed MMADs between 3.6 and $3.9 \mu \mathrm{m}$, and a FPF around $45 \%-50 \%$, thus evidencing the suitable aerodynamic properties for pulmonary delivery with great potential to reach the respiratory zone. FUC-based microparticles had no effect on the cell viability of alveolar epithelial cells (A549), although a slight reduction in the viability of macrophage-differentiated THP-1 cells (65\% viable cells) was observed when exposed for $24 \mathrm{~h}$ to concentrations as high as $1.0 \mathrm{mg} / \mathrm{mL}$. However, this dose is expected to largely overpass that to be observed in vivo. The produced microparticles were further demonstrated to be captured by macrophage-like cells ( $23 \%-87 \%$ uptake) in a dose-dependent manner. Moreover, they were able to induce macrophage activation by potentiating the secretion of cytokines. Furthermore, drug-loaded microparticles showed potential activity against a strain of mycobacteria ( $95 \%$ growth inhibition). According to the obtained data, the proposed delivery carrier, combining two antitubercular drugs in a single formulation, is a promising tool for the inhalable treatment of pulmonary TB. Nevertheless, unveiling the effect of a long-term administration of FUC microparticles in vivo, as well as the in vivo antimicrobial efficacy, are very relevant aspects to address in the future.

Supplementary Materials: The following are available online at http:/ / www.mdpi.com/2073-4360/10/6/636/ s1, Figure S1: Scheme of the 96-well microplate showing columns 4-11 filled with solutions of free drugs or microparticles serially diluted with M7H9 broth, containing mycobacteria in triplicate: lines B-C (suspension 1), lines D-E (suspension 2) and lines F-G (suspension 3). Contents of column 2 (only M7H9 medium) and column 3 (bacterial suspensions in broth) were considered negative and positive control, respectively.

Author Contributions: L.C., S.R. and A.G. conceived and designed the experiments; S.R. performed the experiments concerning microparticle aerosolisation properties, supervised by F.B.; M.L.F. supervised the microbiological experiments. A.M.R.d.C. collaborated with the experiments for preparing fluorescently labelled polymers and supervised chemical analytical experiments. L.C. performed the experiments, analyzed the data and wrote the paper; A.G. supervised and directed the project. All authors reviewed, edited and approved the manuscript.

Acknowledgments: Funding from the Portuguese Foundation for Science and Technology (PTDC/DTP-FTO/ 0094/2012, UID/Multi/04326/2013 and UID/BIM/04773/2013) is acknowledged. Ludmylla Cunha acknowledges Ph.D. grant (BEX 1168/13-4) supported by CAPES-Brazil.

Conflicts of Interest: The authors declare no conflict of interest.

\section{References}

1. World Health Organization (WHO). Global Tuberculosis Report 2017; World Health Organization: Geneva, Switzerland, 2017.

2. Garcia-Contreras, L.; Padilla-Carlin, D.J.; Sung, J.; VerBerkmoes, J.; Muttil, P.; Elbert, K.; Peloquin, C.; Edwards, D.; Hickey, A. Pharmacokinetics of ethionamide delivered in spray-dried microparticles to the lungs of guinea pigs. J. Pharm. 2017, 106, 331-337. [CrossRef] [PubMed]

3. Zumla, A.; Raviglione, M.; Hafner, R.; Reyn, C.F. von Tuberculosis. N. Engl. J. Med. 2013, 368, 745-755. [CrossRef] [PubMed] 
4. Aparna, V.; Shiva, M.; Biswas, R.; Jayakumar, R. Biological macromolecules based targeted nanodrug delivery systems for the treatment of intracellular infections. Int. J. Biol. Macromol. 2018, 110, 2-6. [CrossRef] [PubMed]

5. Tukulula, M.; Gouveia, L.; Paixao, P.; Hayeshi, R.; Naicker, B.; Dube, A. Functionalization of PLGA nanoparticles with 1,3- $\beta$-glucan enhances the intracellular pharmacokinetics of rifampicin in macrophages. Pharm. Res. 2018, 35. [CrossRef] [PubMed]

6. Eedara, B.B.; Rangnekar, B.; Sinha, S.; Doyle, C.; Cavallaro, A.; Das, S.C. Development and characterization of high payload combination dry powders of anti-tubercular drugs for treating pulmonary tuberculosis. Eur. J. Pharm. Sci. 2018, 118, 216-226. [CrossRef] [PubMed]

7. Cunha, L.; Grenha, A. Sulfated seaweed polysaccharides as multifunctional materials in drug delivery applications. Mar. Drugs 2016, 14, 42. [CrossRef] [PubMed]

8. Rodrigues, S.; Grenha, A. Activation of macrophages: Establishing a role for polysaccharides in drug delivery strategies envisaging antibacterial therapy. Curr. Pharm. Des. 2015, 21, 4869-4887. [CrossRef] [PubMed]

9. Jin, J.O.; Yu, Q. Fucoidan delays apoptosis and induces pro-inflammatory cytokine production in human neutrophils. Int. J. Biol. Macromol. 2015, 73, 65-71. [CrossRef] [PubMed]

10. Cho, M.; Lee, D.-J.; Kim, J.-K.; You, S. Molecular characterization and immunomodulatory activity of sulfated fucans from Agarum cribrosum. Carbohydr. Polym. 2014, 113, 507-514. [CrossRef] [PubMed]

11. Borazjani, N.J.; Tabarsa, M.; You, S.; Rezaei, M. Purification, molecular properties, structural characterization, and immunomodulatory activities of water soluble polysaccharides from Sargassum angustifolium. Int. J. Biol. Macromol. 2018, 109, 793-802. [CrossRef] [PubMed]

12. World Health Organization. WHO Treatment Guidelines for Drug-Resistant Tuberculosis 2016; WHO Library Cataloguing-in-Publication Data; World Health Organization: Geneva, Switzerland, 2016.

13. Martinelli, F.; Balducci, A.G.; Kumar, A.; Sonvico, F.; Forbes, B.; Bettini, R.; Buttini, F. Engineered sodium hyaluronate respirable dry powders for pulmonary drug delivery. Int. J. Pharm. 2017, 517, 286-295. [CrossRef] [PubMed]

14. Ota, A.; Istenič, K.; Skrt, M.; Šegatin, N.; Žnidaršič, N.; Kogej, K.; Ulrih, N.P. Encapsulation of pantothenic acid into liposomes and into alginate or alginate-pectin microparticles loaded with liposomes. J. Food Eng. 2018, 229, 21-31. [CrossRef]

15. Prabu, C.; Latha, S.; Selvamani, P.; Ahrentorp, F.; Johansson, C.; Takeda, R.; Takemura, Y.; Ota, S. Layer-by-layer assembled magnetic prednisolone microcapsules (MPC) for controlled and targeted drug release at rheumatoid arthritic joints. J. Magn. Magn. Mater. 2017, 427, 258-267. [CrossRef]

16. European Medicines Agency. Guideline on Quality of Oral Modified Release Products; EMA: Volume EMA/CHMP/QWP/428693/2013; European Medicines Agency: London, UK, 2014.

17. Ahmadi, Z.; Verma, G.; Jha, D. Evaluation of antimicrobial activity and cytotoxicity of pegylated aminoglycosides. J. Bioact. Compat. Polym. 2018, 333, 295-309. [CrossRef]

18. Zhang, L.; Li, Y.; Zhang, Y.; Zhu, C. Sustained release of isoniazid from polylactide microspheres prepared using solid/oil drug loading method for tuberculosis treatment. Sci. China Life Sci. 2016, 59, 724-731. [CrossRef] [PubMed]

19. Jabes, D.; Della Bruna, C.; Rossi, R.; Olliaro, P. Effectiveness of rifabutin alone or in combination with isoniazid in preventive therapy of mouse tuberculosis. Antimicrob. Agents Chemother. 1994, 38, 2346-2350. [CrossRef] [PubMed]

20. Alves, A.; Cavaco, J.; Guerreiro, F.; Lourenço, J.; Rosa da Costa, A.; Grenha, A. Inhalable antitubercular therapy mediated by locust bean gum microparticles. Molecules 2016, 21, 702. [CrossRef] [PubMed]

21. Anshakova, A.V.; Yu Konyukhov, V. Study by inverse gas chromatography of the solubility of rifabutin in water in the presence of cyclodextrin. Russ. J. Appl. Chem. 2017, 90, 209-213. [CrossRef]

22. Pai, R.V.; Jain, R.R.; Bannalikar, A.S.; Menon, M.D. Development and evaluation of chitosan microparticles based dry powder inhalation formulations of rifampicin and rifabutin. J. Aerosol Med. Pulm. Drug Deliv. 2016, 29, 179-195. [CrossRef] [PubMed]

23. Daman, Z.; Gilani, K.; Rouholamini Najafabadi, A.; Eftekhari, H.; Barghi, M. Formulation of inhalable lipid-based salbutamol sulfate microparticles by spray drying technique. DARU J. Pharm. Sci. 2014, 22, 1-9. [CrossRef] [PubMed] 
24. Ni, R.; Zhao, J.; Liu, Q.; Liang, Z.; Muenster, U.; Mao, S. Nanocrystals embedded in chitosan-based respirable swellable microparticles as dry powder for sustained pulmonary drug delivery. Eur. J. Pharm. Sci. 2017, 99, 137-146. [CrossRef] [PubMed]

25. Belotti, S.; Rossi, A.; Colombo, P.; Bettini, R.; Rekkas, D.; Politis, S.; Colombo, G.; Balducci, A.G.; Buttini, F. Spray dried amikacin powder for inhalation in cystic fibrosis patients: A quality by design approach for product construction. Int. J. Pharm. 2014, 471, 507-515. [CrossRef] [PubMed]

26. Takeuchi, I.; Taniguchi, Y.; Tamura, Y.; Ochiai, K.; Makino, K. Effects of L-leucine on PLGA microparticles for pulmonary administration prepared using spray drying: Fine particle fraction and phagocytotic ratio of alveolar macrophages. Colloids Surf. A Physicochem. Eng. Asp. 2018, 537, 411-417. [CrossRef]

27. Sinsuebpol, C.; Chatchawalsaisin, J.; Kulvanich, P. Preparation and in vivo absorption evaluation of spray dried powders containing salmon calcitonin loaded chitosan nanoparticles for pulmonary delivery. Drug Des. Dev. Ther. 2013, 7, 861-873. [CrossRef] [PubMed]

28. Dalpiaz, A.; Fogagnolo, M.; Ferraro, L.; Capuzzo, A.; Pavan, B.; Rassu, G.; Salis, A.; Giunchedi, P.; Gavini, E. Nasal chitosan microparticles target a zidovudine prodrug to brain HIV sanctuaries. Antivir. Res. 2015, 123, 146-157. [CrossRef] [PubMed]

29. Yang, M.Y.; Chan, J.G.Y.; Chan, H.K. Pulmonary drug delivery by powder aerosols. J. Control. Release 2014, 193, 228-240. [CrossRef] [PubMed]

30. Martinelli, F.; Balducci, A.G.; Rossi, A.; Sonvico, F.; Colombo, P.; Buttini, F. "Pierce and inhale" design in capsule based dry powder inhalers: Effect of capsule piercing and motion on aerodynamic performance of drugs. Int. J. Pharm. 2015, 487, 197-204. [CrossRef] [PubMed]

31. Buttini, F.; Hannon, J.; Saavedra, K.; Rossi, I.; Balducci, A.G.; Smyth, H.; Clark, A. Accessorized DPI: A shortcut towards flexibility and patient adaptability in dry powder inhalation. Pharm. Res. 2016, 3012-3020. [CrossRef] [PubMed]

32. Buttini, F.; Colombo, G.; Kwok, P.C.L.; Wui, W.T. Aerodynamic assessment for inhalation products: Fundamentals and current pharmacopoeial methods. In Inhalation Drug Delivery: Techniques and Products; Colombo, P., Traini, D., Buttini, F., Eds.; Wiley-Blackwell: West Sussex, UK, 2013; pp. 91-119.

33. Buttini, F.; Brambilla, G.; Copelli, D.; Sisti, V.; Balducci, A.G.; Bettini, R.; Pasquali, I. Effect of flow rate on in vitro aerodynamic performance of NEXThaler ${ }^{\circledR}$ in comparison with Diskus ${ }^{\circledR}$ and Turbohaler ${ }^{\circledR}$ Dry Powder Inhalers. J. Aerosol Med. Pulm. Drug Deliv. 2016, 29, 167-178. [CrossRef] [PubMed]

34. Hirota, K.; Hasegawa, T.; Hinata, H.; Ito, F.; Inagawa, H.; Kochi, C.; Soma, G.I.; Makino, K.; Terada, H. Optimum conditions for efficient phagocytosis of rifampicin-loaded PLGA microspheres by alveolar macrophages. J. Control. Release 2007, 119, 69-76. [CrossRef] [PubMed]

35. Eleftheriadis, G.K.; Akrivou, M.; Bouropoulos, N.; Tsibouklis, J.; Vizirianakis, I.S.; Fatouros, D.G. Polymer-lipid microparticles for pulmonary delivery. Langmuir 2018, 34, 3438-3448. [CrossRef] [PubMed]

36. Mulla, J.A.S.; Mabrouk, M.; Choonara, Y.E.; Kumar, P.; Chejara, D.R.; du Toit, L.C.; Pillay, V. Development of respirable rifampicin-loaded nano-lipomer composites by microemulsion-spray drying for pulmonary delivery. J. Drug Deliv. Sci. Technol. 2017, 41, 13-19. [CrossRef]

37. Vieira, A.C.; Magalhães, J.; Rocha, S.; Cardoso, M.S.; Santos, S.G.; Borges, M.; Pinheiro, M.; Reis, S. Targeted macrophages delivery of rifampicin-loaded lipid nanoparticles to improve tuberculosis treatment. Nanomedicine 2017, 12, 2721-2736. [CrossRef] [PubMed]

38. Oliveira, P.M.; Matos, B.N.; Pereira, P.A.T.; Gratieri, T.; Faccioli, L.H.; Cunha-Filho, M.; Gelfuso, G.M. Microparticles prepared with 50-190 kDa chitosan as promising non-toxic carriers for pulmonary delivery of isoniazid. Carbohydr. Polym. 2017, 17, 1-35. [CrossRef] [PubMed]

39. Haghi, M.; Ong, H.X.; Traini, D.; Young, P. Across the pulmonary epithelial barrier: Integration of physicochemical properties and human cell models to study pulmonary drug formulations. Pharmacol. Ther. 2014, 144, 235-252. [CrossRef] [PubMed]

40. Bur, M.; Huwer, H.; Muys, L.; Lehr, C.-M. Drug transport across pulmonary epithelial cell monolayers: Effects of particle size, apical liquid volume, and deposition technique. J. Aerosol Med. Pulm. Drug Deliv. 2010, 23, 119-127. [CrossRef] [PubMed]

41. ISO 10993-5: 2009. Biological Evaluation of Medical Devices Part 5: Tests for In Vitro Cytotoxicity; International Organization for Standardization: Geneva, Switzerland, 2009. 
42. Rodrigues, S.; Alves, A.D.; Cavaco, J.S.; Pontes, J.F.; Guerreiro, F.; Rosa da Costa, A.M.; Buttini, F.; Grenha, A. Dual antibiotherapy of tuberculosis mediated by inhalable locust bean gum microparticles. Int. J. Pharm. 2017, 529, 433-441. [CrossRef] [PubMed]

43. Barluenga, J.; Aznar, F.; García, A.B.; Cabal, M.P.; Palacios, J.J.; Menéndez, M.A. New rifabutin analogs: Synthesis and biological activity against Mycobacterium tuberculosis. Bioorganic Med. Chem. Lett. 2006, 16, 5717-5722. [CrossRef] [PubMed]

44. Chien, J.-Y.; Chien, S.-T.; Huang, S.-Y.; Yu, C.-J. Safety of rifabutin replacing rifampicin in the treatment of tuberculosis: A single-centre retrospective cohort study. J. Antimicrob. Chemother. 2014, 69, 790-796. [CrossRef] [PubMed]

45. Chakraborty, P.; Kulkarni, S.; Rajan, R.; Sainis, K. Mycobacterium tuberculosis strains from ancient and modern lineages induce distinct patterns of immune responses. J. Infect. Dev. Ctries. 2017, 11, 904-911. [CrossRef]

46. Mwandumba, H.C.; Squire, S.B.; White, S.A.; Nyirenda, M.H.; Zijlstra, E.E.; Molyneux, M.E.; Russell, D.G.; Rhoades, E.R. Alveolar macrophages from HIV-infected patients with pulmonary tuberculosis retain the capacity to respond to stimulation by lipopolysaccharide. Microbes Infect. 2007, 9, 1053-1060. [CrossRef] [PubMed]

47. Duque, G.A.; Descoteaux, A. Macrophage cytokines: Involvement in immunity and infectious diseases. Front. Immunol. 2014, 5, 1-12. [CrossRef]

48. Stefaniak-Vidarsson, M.M.; Gudjónsdóttir, M.; Marteinsdottir, G. Evaluation of bioactivity of fucoidan from laminaria with in vitro human cell culture (THP-1). Funct. Foods Health Dis. 2017, 7, 688-701.

49. Zhang, W.; Oda, T.; Yu, Q.; Jin, J.-O. Fucoidan from macrocystis pyrifera has powerful immune-modulatory effects compared to three other fucoidans. Mar. Drugs 2015, 13, 1084-1104. [CrossRef] [PubMed]

50. Telles, C.B.S.; Mendes-Aguiar, C.; Fidelis, G.P.; Frasson, A.P.; Pereira, W.O.; Scortecci, K.C.; Camara, R.B.G.; Nobre, L.T.D.B.; Costa, L.S.; Tasca, T. Immunomodulatory effects and antimicrobial activity of heterofucans from Sargassum filipendula. J. Appl. Phycol. 2017, 30, 569-578. [CrossRef]

51. Jin, J.O.; Park, H.Y.; Xu, Q.; Park, J.I.; Zvyagintseva, T.; Stonik, V.A.; Kwak, J.Y. Ligand of scavenger receptor class A indirectly induces maturation of human blood dendritic cells via production of tumor necrosis factor- $\alpha$. Blood 2009, 113, 5839-5848. [CrossRef] [PubMed]

52. Li, J.; Chen, K.; Li, S.; Liu, T.; Wang, F.; Xia, Y.; Lu, J.; Zhou, Y.; Guo, C. Pretreatment with fucoidan from fucus vesiculosus protected against conA-induced acute liver injury by inhibiting both intrinsic and extrinsic apoptosis. PLoS ONE 2016, 11, 1-16. [CrossRef] [PubMed]

53. Park, J.; Cha, J.D.; Choi, K.M.; Lee, K.Y.; Han, K.M.; Jang, Y.S. Fucoidan inhibits LPS-induced inflammation in vitro and during the acute response in vivo. Int. Immunopharmacol. 2017, 43, 91-98. [CrossRef] [PubMed]

54. Marianelli, C.; Armas, F.; Boniotti, M.B.; Mazzone, P.; Pacciarini, M.L.; Di Marco Lo Presti, V. Multiple drug-susceptibility screening in Mycobacterium bovis: New nucleotide polymorphisms in the embB gene among ethambutol susceptible strains. Int. J. Infect. Dis. 2015, 33, 39-44. [CrossRef] [PubMed]

55. Sturegård, E.; Ängeby, K.A.; Werngren, J.; Juréen, P.; Kronvall, G.; Giske, C.G.; Kahlmeter, G.; Schön, T. Little difference between minimum inhibitory concentrations of Mycobacterium tuberculosis wild-type organisms determined with BACTEC MGIT 960 and Middlebrook 7H10. Clin. Microbiol. Infect. 2015, 21, 148.e5-148.e7. [CrossRef] [PubMed]

56. Pinheiro, M.; Silva, A.S.; Reis, S. Molecular interactions of rifabutin with membrane under acidic conditions. Int. J. Pharm. 2015, 479, 63-69. [CrossRef] [PubMed]

57. Pinheiro, M.; Nunes, C.; Caio, J.M.; Moiteiro, C.; Lúcio, M.; Brezesinski, G.; Reis, S. The influence of Rifabutin on human and bacterial membrane models: Implications for its mechanism of action. J. Phys. Chem. B 2013, 117, 6187-6193. [CrossRef] [PubMed]

58. Ritz, N.; Tebruegge, M.; Connell, T.G.; Sievers, A.; Robins-Browne, R.; Curtis, N. Susceptibility of Mycobacterium bovis BCG vaccine strains to antituberculous antibiotics. Antimicrob. Agents Chemother. 2009, 53, 316-318. [CrossRef] [PubMed]

59. Sirgel, F.A.; Warren, R.M.; Böttger, E.C.; Klopper, M.; Victor, T.C.; van Helden, P.D. The Rationale for Using Rifabutin in the Treatment of MDR and XDR Tuberculosis Outbreaks. PLoS ONE 2013, 8, 1-5. [CrossRef] [PubMed]

(C) 2018 by the authors. Licensee MDPI, Basel, Switzerland. This article is an open access article distributed under the terms and conditions of the Creative Commons Attribution (CC BY) license (http://creativecommons.org/licenses/by/4.0/). 